\title{
Serotonergic and noradrenergic response of ethanol extract; opioidergic response of ethyl acetate extract of Dicranopteris linearis L. leaf
}

Mohammad Mustakim Billah ${ }^{1 *}$ B, Ayreen Sonia Chowdhury², Kashfia Nawrin', Saqline Mostaq², Md. Abu Rayhan ${ }^{3}$ and Razwanur Rahman Tushar ${ }^{4}$

\begin{abstract}
Background: Dicranopteris linearis L. is among the popular tribal plants used for various ailments, although many of its pharmacological potentials have not been investigated yet. The neuropharmacological potentials of the leaf, including sedative-anxiolytic potential, were previously studied however, the antidepressant activity was yet to be examined. Thus, this study was aimed to investigate the serotonergic, noradrenergic and opioidergic response of $D$. linearis leaf extracts.

Methods: The plant leaf was extracted in three solvents- water (DLAQ), ethanol (DLET) and ethyl acetate (DLEA) and applied each in 200 and $400 \mathrm{mg} \cdot \mathrm{kg}^{-1}$ per body weight of Swiss Albino mice. Forced Swim Test (FST) and Tail Suspension Test (TST) were conducted to evaluate antidepressant potential. In FST, latency and duration of immobility, swimming and climbing time were recorded. In TST, immobility, swinging, curling and pedaling were observed. Alongside, preliminary screening through acute toxicity study and pentobarbitone induced sleep test were performed.

Results: Both in FST and TST, the duration of immobility was reduced by the standard imipramine and DLET 200 and 400. In FST, DLEA 200 and 400 increased the climbing time suggesting noradrenergic mechanism of action and decreased the swimming time suggesting deficit of serotoninergic mechanism of action. Interestingly, DLET increased both the parameters presenting a dual action. However, in TST, DLEA decreased immobility but increased swinging and curling response which indicated its opioidergic mechanism. On the other hand, DLET proved to mediate through serotonin and/or NA reuptake mechanism by having decreased curling time.

Conclusion: Among the three extracts, the ethanol extract proved to be more potent. DLET mimicked the standard imipramine in all parameters except for the curling behavior. The result thus suggests $D$. linearis as a potent antidepressant agent however, recommends its medicinal use after further investigation to identify bioactive compounds.
\end{abstract}

Keywords: Dicranopteris linearis, Forced swim test, Tail suspension test, Antidepressants

\footnotetext{
* Correspondence: mustakimbillah@hotmail.com

'Department of Pharmacology, Institute for Pharmaceutical Skill

Development and Research, Dhaka, Bangladesh

Full list of author information is available at the end of the article
}

\section{Springer Open}

(c) The Author(s). 2021 Open Access This article is licensed under a Creative Commons Attribution 4.0 International License, which permits use, sharing, adaptation, distribution and reproduction in any medium or format, as long as you give appropriate credit to the original author(s) and the source, provide a link to the Creative Commons licence, and indicate if changes were made. The images or other third party material in this article are included in the article's Creative Commons licence, unless indicated otherwise in a credit line to the material. If material is not included in the article's Creative Commons licence and your intended use is not permitted by statutory regulation or exceeds the permitted use, you will need to obtain permission directly from the copyright holder. To view a copy of this licence, visit http://creativecommons.org/licenses/by/4.0/. 


\section{Introduction}

Dicranopteris linearis is a popular healer member of the Gleicheniaceae family of medicinal plants. It is prescribed for various ailments in different parts of Bangladesh in different localities. The plant is characterized as forking fern by its segmented leaves in linear shape which grows up to $7 \mathrm{~cm}$ in length and by a few millimeters in width with hairy and waxy underside [1]. Studies found that the Garo tribes of Haluaghat (Mymensingh) prescribes a juice prepared from the young leaf for the treatment of cough, allergic symptoms and respiratory troubles [2]. Traditional uses around the globe were found reported in literature supporting its efficacy to alleviate fever (Malaysia); to treat ulcers, boils and topical wound (Papua New Guinea); to protect against intestinal worms (Indochina) and to pacify asthma and treat woman's sterility (India) [3]. Scientifically investigated pharmacological activities include analgesic, antipyretic, anti-inflammatory, antibacterial, antioxidant, hepatoprotective, gastroprotective and cytotoxic response whereas more potential activities are still under investigation [3-7]. The leaf processed as a drink or as poultice for external use is often prescribed [8].

The search for neuropharmacological potential of medicinal plants has always been crucial due to the limited numbers of agents in the therapeutic line with proven efficacy. The ability of leaf of $D$. linearis to control muscarinic receptors proposes for new therapeutic use against Alzheimer's disease and schizophrenia [9, 10]. Though other studies have focused on the anxiolytic and sedative responses [1], no studies have been reported on the antidepressant investigation of the $D$. linearis leaf. Moreover, finding effective pharmacotherapy for major depressive disorders has been a major challenge for long. The time demand together with the proven neuropharmacological efficacy of this plant makes it a potential candidate for evaluating antidepressant activities as well. The present study was thus designed to investigate the antidepressant potential of the leaf of $D$. linearis by a comparison of three different solvent extracts.

\section{Methodology}

\section{Preparation of extract}

Approximately $6-7 \mathrm{~kg}$ of $D$. linearis leaf was collected from the district of Mymensingh $\left(24^{\circ} 45^{\prime} 14^{\prime \prime} \mathrm{N} 90^{\circ} 24^{\prime}\right.$ $\left.11^{\prime \prime} \mathrm{E}\right)$ of Bangladesh in Jun, 2014. After collection the leaf was identified by Bangladesh National Herbarium and a sample specimen was kept with the accession number DACB 42009. The leaf was first washed thoroughly to clean from dust and dirt. These are sun dried and crushed in to powder (approximately $600 \mathrm{~g}$ ) with a grinder. Then the powder was immersed separately in three different solvents for 7 days to get aqueous (DLAQ), ethanol (DLET) and ethyl acetate (DLEA) extracts. Finally, the solution was filtered with cellulose filter paper and condensed with the help of rotary evaporator to make viscous leaf extracts [11].

\section{Drugs and reagents}

Imipramine Hydrochloride (Incepta Pharmaceuticals Ltd.), Sodium Pentobarbitone (Sigma-Aldrich Inc.), Diazepam (Square Pharmaceuticals Ltd.), Caffeine (Square Pharmaceuticals Ltd.), Ethanol (Merck, Germany) and Ethyl Acetate (Merck, Germany) were obtained for the experiments.

\section{Preliminary screening Acute toxicity study}

Sixteen groups $(n=5)$ of male-female Swiss Albino mice were isolated for acute toxicity test and those were not re-selected for any further investigation. They were exposed to high strengths $(250 \mathrm{mg} / \mathrm{kg}, 500 \mathrm{mg} / \mathrm{kg}, 1000$ $\mathrm{mg} / \mathrm{kg}, 2000 \mathrm{mg} / \mathrm{kg}, 3000 \mathrm{mg} / \mathrm{kg}$ per body weight) of the test agents alongside a control group (did not receive any extract) by oral administration and observed for next $72 \mathrm{~h}$ for any lethality.

\section{Pentobarbitone induced sleeping time test}

The test was performed to investigate the sedation and stimulation potential of the extracts in doses to be tested on mice. Female mice were randomly assigned to nine groups $(n=6)$ and orally received either $D$. linearis extracts (DLAQ 200, DLAQ 400, DLET 200, DLET 400, DLEA 200, DLEA $400 \mathrm{mg} \cdot \mathrm{kg}^{-1}$ b.w.) as test agents, diazepam ( $1 \mathrm{mg} \cdot \mathrm{kg}^{-1}$ b.w.) as sedative standard, caffeine (5 mg. $\mathrm{kg}^{-1}$ b.w.) as stimulating standard, or $1 \%$ tween in distilled water $\left(10 \mathrm{ml} . \mathrm{kg}^{-1}\right.$ b.w.) as negative control. Sleep was induced to the rodents by intraperitoneal injection of $50 \mathrm{mg} \cdot \mathrm{kg}^{-1}$ sodium pentobarbitone, $1 \mathrm{~h}$ after respective drug treatments. The observation of latency to sleep as defined by the time between pentobarbitone injection and loss of righting reflex and duration of sleep as the time between loss of and regaining of righting reflex were recorded [12].

\section{Acute antidepressant tests Animal groups}

Fresh Swiss Albino mice with sound health and mental conditions, female aged 40-45 days, weighed 25-30 g were selected for the studies. Prior each experiment, eight groups were formed consisting six mice in each depending upon the treatment they received. The groups were as followed: control (dH2O), standard (imipramine hydrochloride 3 (mg. $\left.\mathrm{kg}^{-1}\right)$, DLAQ $200\left(\mathrm{mg} \cdot \mathrm{kg}^{-1}\right)$, DLAQ $400 \quad\left(\mathrm{mg}^{\mathrm{kg}}{ }^{-1}\right)$, DLET $200 \quad\left(\mathrm{mg} \cdot \mathrm{kg}^{-1}\right)$, DLET 400 $\left(\mathrm{mg} \cdot \mathrm{kg}^{-1}\right)$, DLEA $200 \quad\left(\mathrm{mg} \cdot \mathrm{kg}^{-1}\right)$ and DLEA 400 (mg.kg ${ }^{-1}$ ) as per body weight. Standard animal handling 
and treatment guideline was followed for all the investigations [13].

\section{Forced swim test}

In this experiment mice were subjected to forced swim when dropped in a water filled $(15 \mathrm{~cm})$ top open glass cylinder $(25 \times 15 \times 25 \mathrm{~cm})$ to check the immobility [8]. Sixty minutes after oral administration of the test agents, mice were placed in the water $\left(24 \pm 1^{\circ} \mathrm{C}\right)$ and observed for the duration of immobility, latency to immobility, climbing, and swimming for the next four minutes to check the anti-depressant activity. First one minute of this study were excluded to avoid handling shock. Imipramine hydrochloride and distilled water served as the positive and negative controls respectively for this study. After the exposure period, animals were withdrawn from the cylinder and gently dried with a towel and kept in a warm place until completely dried. The increase in latency and decrease in duration of immobility typically indicate antidepressant-like activities. Whereas the escape-oriented behavior like climbing and swimming give clues to predict possible mechanisms of action of the test agents [14].

\section{Tail suspension test}

Tail suspension is another mode of investigation of immobility exhibited by the mice when they are hanged by the tail [9]. One hour after the oral gavage of the test agents, mice were marked at $1 \mathrm{~cm}$ from the tip of the tail. Imipramine hydrochloride was used as the positive standard for this experiment. They were hanged at the tip $50 \mathrm{~cm}$ above the ground and kept suspended for the next four minutes where the last three minutes were observed for the immobility time (without engaging in any active behavior), swinging time (continuously moving its paws in vertical position keeping body straight and/or moving body side to side), curling time (engaged in active twisting movements of entire body) and pedaling (moved its paw continuously without moving its body). During the experiment, any mice climbed by its tail, was gently pulled down and allowed to proceed with the experiment [15].

\section{Statistical significance}

One-way analysis of variance (ANOVA) followed by Dunnett's $t$ tests were performed for statistical analysis of data using SPSS 20 for windows. All results were compared with the negative control where $P$ values $<0.05,0.01$ and 0.001 were considered to be statistically significant.

\section{Results}

Acute toxicity study

Oral administration of high doses of the test agents produced no lethal effect however were associated with abnormal conditions. Table 1 showed that the aqueous, ethanol and ethyl acetate extracts at $3000 \mathrm{mg} \cdot \mathrm{kg}^{-1}$ per body weight caused indigestion. The toxicity study aided to design safe dose line for further investigation.

\section{Pentobarbitone induced sleeping time test (PIST)}

After pentobarbitone pretreatment the acute administration of $D$. linearis extracts showed decrease in latency of losing the righting reflex in which DLAQ 400, DLEA 200 and $400 \mathrm{mg} \cdot \mathrm{kg}^{-1}$ were found significant $(p<0.5)$ compared to control. Maximum reduction in latency was observed by Diazepam $\left(1 \mathrm{mg} \cdot \mathrm{kg}^{-1}\right)$ in $4.2 \mathrm{~min}$ whereas the CNS stimulant caffeine $\left(16 \mathrm{mg} \cdot \mathrm{kg}^{-1}\right)$ prolonged the onset till 26.4 min (Fig. 1a).

Figure $1 \mathrm{~b}$ showed diazepam significantly $(\mathrm{p}<0.001)$ increased the duration of sleep (126.75 $\mathrm{min}$ ) in comparison with control $(48.24 \mathrm{~min})$. DLEA 200 followed the same pattern $(86.00 \mathrm{~min}, p<0.5)$. On the contrary, caffeine exhibited the shortest sleeping time $(29.45 \mathrm{~min})$ among all groups.

\section{Antidepressant tests \\ Forced swim test (FST)}

The duration of the animals exhibited with no physical action in the swimming cylinder was found minimum (53.25 s) with imipramine $1 \mathrm{mg} \cdot \mathrm{kg}^{-1}$ (Fig. 2a). DLET 400 closely mimicked $(59.5 \mathrm{~s})$ the standard. Both DLAQ and DLEA found to have mild effect on decreasing the activity at higher dose $\left(400 \mathrm{mg} \cdot \mathrm{kg}^{-1}\right)$. Figure $2 \mathrm{~b}$ demonstrated that the latency to immobile condition was significantly increased by DLET $200(p<0.05)$ and $400(p<0.01)$ next to imipramine $(p<0.001)$.

The climbing response was found highest with DLEA 200 (57.85 s, $p<0.01$ ) compared to control (20.75 s). Imipramine exhibited the lowest response $(10.25 \mathrm{~s})$ and DLET 400 followed to reduce the forced activity (Fig. 2c). The standard also significantly $(p<0.01)$ increased the swimming activity while DLET 400 showed similar response (Fig. 2d).

\section{Tail suspension test (TST)}

Like forced swim test, DLET (400 mg/Kg b.w) showed a decrease in the immobility time $(51.35 \mathrm{~s} p<0.05)$ compared to the standard drug imipramine $(46.50 \mathrm{~s}, \mathrm{p}<0.01)$ (Fig. 3a). All other test groups could not establish significant difference with the control (108.75 s). Figure 3b depicts that control mice did not produce much swinging activity. On the contrary, imipramine, DLET 400 and DLEA 400 significantly increase the activity.

Figure $3 \mathrm{c}$ showed that the curling response in tail suspension test was increased by imipramine, DLAQ 200 and DLEA 400. DLET inversely acted to decrease the activity. Among the three extracts DLAQ 400 was able to reduce the pedaling time by the mice in comparison 
Table 1 Acute Toxicity Study Report of D. linearis leaf extract

\begin{tabular}{|c|c|c|c|c|}
\hline Groups & Test Agents & Dose Strength (mg.kg ${ }^{-1}$ b.w.) & Lethality (D/T) & Abnormal Effect \\
\hline 1 & d. $\mathrm{H}_{2} \mathrm{O}$ (control) & 0 & $0 / 5$ & - \\
\hline 2 & DLAQ & 250 & $0 / 5$ & - \\
\hline 3 & DLAQ & 500 & $0 / 5$ & - \\
\hline 4 & DLAQ & 1000 & $0 / 5$ & - \\
\hline 5 & DLAQ & 2000 & $0 / 5$ & - \\
\hline 6 & DLAQ & 3000 & $0 / 5$ & Indigestion \\
\hline 7 & DLET & 250 & $0 / 5$ & - \\
\hline 8 & DLET & 500 & $0 / 5$ & - \\
\hline 9 & DLET & 1000 & $0 / 5$ & - \\
\hline 10 & DLET & 2000 & $0 / 5$ & Indigestion \\
\hline 11 & DLET & 3000 & $0 / 5$ & Indigestion \\
\hline 12 & DLEA & 250 & $0 / 5$ & - \\
\hline 13 & DLEA & 500 & $0 / 5$ & - \\
\hline 14 & DLEA & 1000 & $0 / 5$ & - \\
\hline 15 & DLEA & 2000 & $0 / 5$ & - \\
\hline 16 & DLEA & 3000 & $0 / 5$ & Indigestion \\
\hline
\end{tabular}

$\mathrm{D}=$ Deaths recorded, $\mathrm{T}=$ Total numbers treated, $\mathrm{DLAQ}=$ Aqueous extract of $D$. linearis, DLET $=$ Ethanol extract of $D$. linearis, DLEA = Ethyl Acetate extract of of D. linearis

with the control though having no significant difference (Fig. 3d).

\section{Discussion}

Acute toxicity study is often considered a determinant for safe dose lining. The present study suggested that $D$. linearis leaf extracts were free from the risks of mortality at the given doses. However, abnormalities in digestion were observed at very high doses (3000 mg. $\mathrm{kg}^{-1}$ ) which was also evident in comparatively lower doses (2000 mg. $\mathrm{kg}^{-1}$ ) but particularly for ethanol extract. The indigestion was characterized by slightly olive to greenish stools compared to that of observed in mice administered with lower doses.
The leaf of D. linearis contains high total phenolic content (TPC), flavonoids (particuarly of flavonol 3Oglycosides types), triterpenes, saponins and high content of steroids $[16,17]$. Preparation of the leaf in three different solvents potentiate the chance of extracting maximum number of the bioactive components. Aqueous extract contained polar; ethanol held slightly polar to nonpolar while ethyl acetate obtained the nonpolar compounds [1]. The presence of phenolic compounds demonstrates good antidepressant-like activity [18-20]. Flavonoids plays a vital role in exhibiting antidepressantlike activity [21]. Direct evidences of such activity by triterpenes and saponins through FST and TST were reported in the literatures [22, 23]. Moreover, studies (a) Latency to sleep in PIST

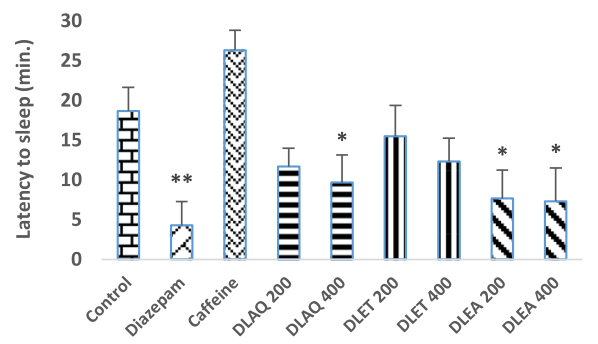

(b) Duration of sleep in PIST

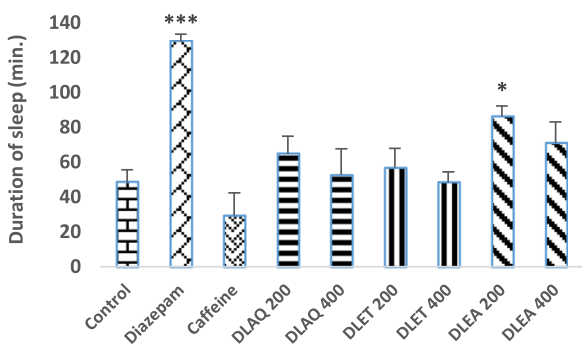

Fig. 1 a-b: Observation parameters of Pentobarbitone Induced Sleeping Time Test (PIST). Figure represented the latency to sleep (a) and duration of sleep (b) in minutes exhibited by the respective groups of mice. DLAQ = Aqueous extract of $D$. linearis, DLET=Ethanol extract of $D$. linearis, $\mathrm{DLEA}=$ Ethyl Acetate extract of of $D$. linearis. Data represented as mean + SEM and analyzed by one-way ANOVA followed by Dunnett $t$ test where ${ }^{*}{ }^{* *},{ }^{* * *}$ denoted $p<0.05, p<0.01$ and $p<0.001$ respectively and statistically significant. All groups ( $\left.n=6\right)$ were compared to control 
(a) Immobility time in FST

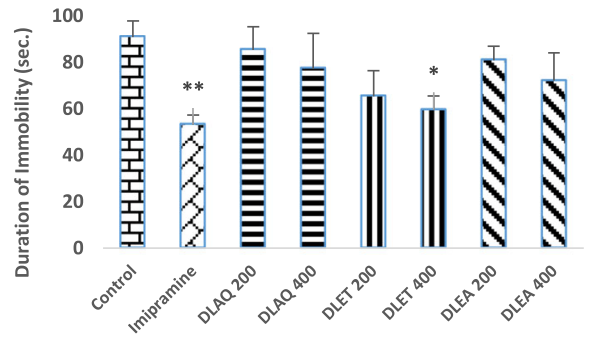

(c) Climbing Response in FST

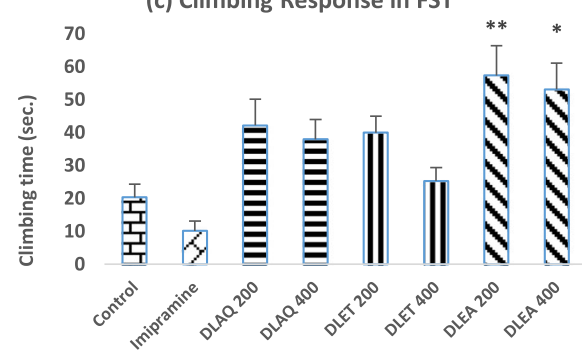

(b) Latency of immobility in FST
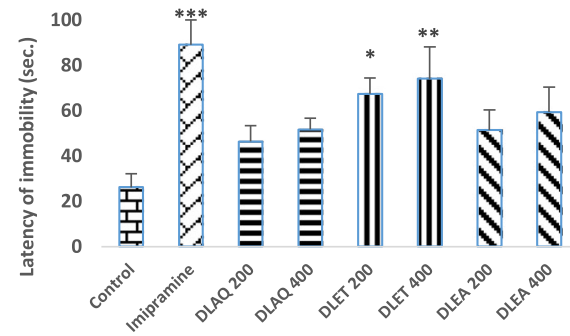

(d) Swimming Response in FST

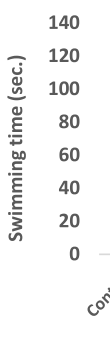

兵

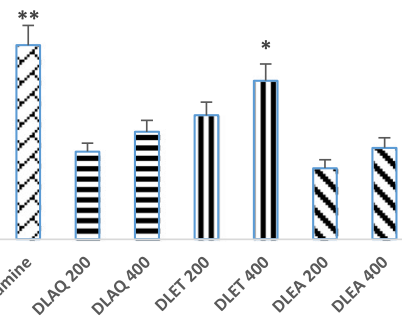

Fig. 2 a-d: Observation parameters of Forced Swim Test (FST). Figure represented the duration of immobility (a), latency of immobility (b), climbing time $(\mathbf{c})$ and swimming time $(\mathbf{d})$ measured in seconds exhibited by the respective groups of mice. DLAQ $=A q u e o u s$ extract of $D$. linearis, DLET $=$ Ethanol extract of $D$. linearis, DLEA = Ethyl Acetate extract of of $D$. linearis. Data represented as mean + SEM and analyzed by one-way ANOVA followed by Dunnett t test where ${ }^{*},{ }^{* *}{ }^{* * *}$ denoted $p<0.05, p<0.01$ and $p<0.001$ respectively and statistically significant. All groups $(n=6)$ were compared to control

(a) Immobility time in TST

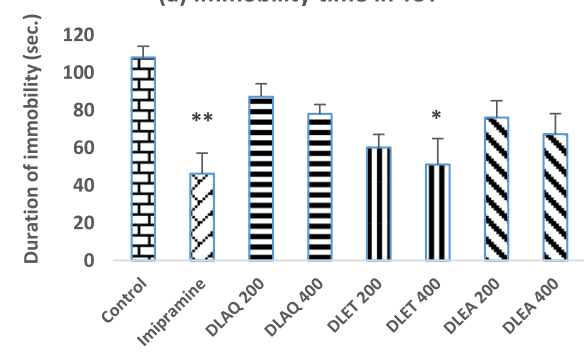

(c) Curling Response in TST

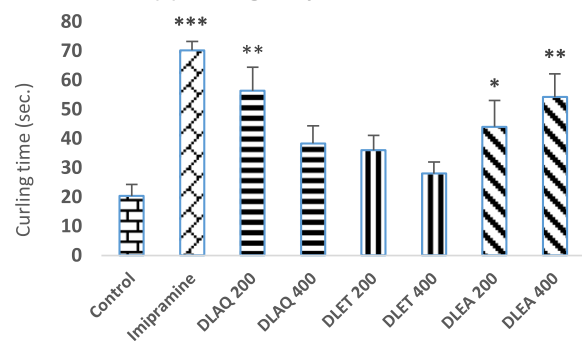

(b) Swinging Response in TST
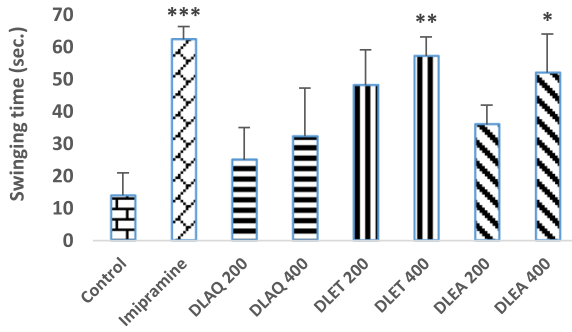

(d) Padeling Response in TST

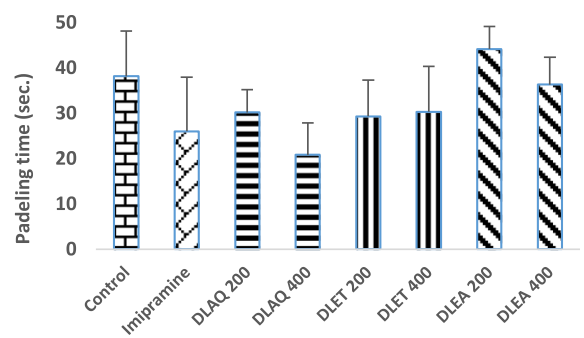

Fig. 3 a-d: Observation parameters of Tail Suspension Test (TST). Figure represented the duration of immobility (a), swinging response (b), curling time $(\mathbf{c})$ and pedaling time $(\mathbf{d})$ measured in seconds exhibited by the respective groups of mice. DLAQ = Aqueous extract of $D$. linearis, DLET = Ethanol extract of $D$. linearis, DLEA = Ethyl Acetate extract of of $D$. linearis. Data represented as mean + SEM and analyzed by one-way ANOVA followed by Dunnett $t$ test where ${ }^{*}, * * * *$ denoted $p<0.05, p<0.01$ and $p<0.001$ respectively and statistically significant. All groups $(n=6)$ were compared to control 
proved that steroids are found to reduce the immobility in FST $[24,25]$. Further investigation is required to identify the particularly responsible bioactive compounds which can validate the claims of this study.

In FST, antidepressants acting through the serotonergic system decrease the immobility period and selectively increase the swimming response [26]. In addition, increase in climbing behavior is observed with the drug acts through noradrenergic mechanism [27, 28]. The data showed DLEA 200 and 400 had an increase in climbing response suggesting the involvement of noradrenergic mechanism however, the decrease in swimming activity reversed the possibilities of a serotonin mediated response. On the other side, DLET in both cases increased the response indicating dual effects $[29,30]$. Like imipramine, DLET increased the latency to immobile condition but significantly reduced the duration of immobility resulting in antidepressant-like activity.

Similarly, in TST, antidepressants act through inhibiting serotonin and/or NA reuptake, decrease immobility and increase swinging behavior of the animal [26]. One the contrary, opioids result in decreased immobility and increased curling behavior [31]. DLEA was found with decreased immobility but increased swinging and curling response as like imipramine suggesting the possible involvement of opioidergic mechanism. DLET increased the swinging response and reduced the immobility time but unlikely also reduced the curling activity. Arbitrary pedaling activity was observed with no significant difference with the control.

Pentobarbitone is a barbituric acid derivative which help induces sleep in rodents by binding GABA receptor complex. The drug is used for GABA mediated hyperpolarization of postsynaptic neurons. Pentobarbitone induced sleep test involves mechanism of GABA potentiation and hindrance of excitatory glutamate receptor, which all together produces molecular action lead to abate neuronal activity [32]. In this study, none of the extracts exhibited extreme duration of sleep which can be attributed to a sedative potential. The antidepressant-like activity of the extracts thus seems not to be associated with the sleep.

\section{Conclusion}

Antidepressant-like activity was measured with forced activity tests where inactivity represented the development of confidence level which was an indication of antidepressant-like activity. Standard drug imipramine showed a decrease in the duration of immobility alternatively increasing the swimming time. In search of the antidepressant-like activity by the extracts of $D$. linearis, ethanol extract proved to be highly potent among others. Ethyl acetate extract resulted in some interesting findings regarding the hypothesis of its mechanism which eventually demanded a new area of investigation. Further phytochemical screening and in vitro analysis is recommended to establish the scientific basis of its activity.

\section{Abbreviations}

DLAQ: Aqueous extract of D. linearis; DLET: Ethanol extract of $D$. linearis: DLEA: Ethyl Acetate extract of of D. linearis.; b.w: Body weight; i.p: Intraperitoneal; p.o.: Per oral; GABA: Gamma-Amino Butyric Acid; TST: Tail Suspension Test; FST: Forced Swim Test; CNS: Central Nervous System; NA: Noradrenaline

\section{Acknowledgments}

The present study was supported and carried out in the Pharmacology lab of Institute for Pharmaceutical Skill Development and Research, Bangladesh. Authors are grateful to the institution for providing such opportunity to contribute to health science. Authors are also grateful to Bangladesh National Herbarium for identifying the plant and preserving the specimen.

\section{Authors' contributions}

This work was carried out in collaboration between all authors. Authors MMB and $\mathrm{KN}$ designed coordinated and supervised the project. ASC performed in vivo experiments and prepared the graphical presentations. MSM participated in the experiments and analyzed the data. Authors MAR prepared the extracts, coordinated the preliminary screening and prepared the manuscript. MRA participated in interpretation of data to reach a scientific discussion and critically revised the manuscript. All authors read and approved the final manuscript.

\section{Funding}

This research did not receive any specific grant from funding agencies in the public, commercial, or not-for-profit sectors.

\section{Availability of data and materials}

The datasets used and/or analyzed during the current study are available from the corresponding author on reasonable request.

\section{Ethics approval and consent to participate}

All experiments associated with animal handling were performed in accordance with the Guide for the Care and Use of Laboratory Animals, 8th ed.; The National Academies Collection adopted by the institutional guideline for animal handling (Ref. no. IPSDRLAB/AHCP/01/18). The experimental design was authorized by the Institutional Ethical Committee Clearance (Ref. No. IPSDRLAB/IECC/17/19) of Institute for Pharmaceutical Skill Development and Research, Bangladesh (project approved on 20/11/2019).

\section{Consent for publication}

Not applicable.

\section{Competing interests}

All authors agreed on the article before submission and had no conflict of interests.

\section{Author details}

${ }^{1}$ Department of Pharmacology, Institute for Pharmaceutical Skill Development and Research, Dhaka, Bangladesh. ${ }^{2}$ Department of Pharmacy, University of Asia Pacific, Dhaka, Bangladesh. ${ }^{3}$ National Cancer Centre Graduate School of Cancer Science and Policy (NCC-GCSP), Goyang-si, South Korea. ${ }^{4}$ Department of Pharmacy, State University of Bangladesh, Dhaka, Bangladesh.

Received: 29 July 2020 Accepted: 9 February 2021

Published online: 19 February 2021

\section{References}

1. Billah MM, Nawrin K, Ahmed KT, Jabed MSU, Islam MN, Uddin MM. GABA mediated response of aqueous, ethanol and ethyl acetate extracts of Dicranopteris linearis leaf in Swiss albino mice. J Herbmed Pharmacol. 2015; 5(1):1-6 http://www.herbmedpharmacol.com/Article/JHP 20151203110517 (accessed 7 Jul 2020). 
2. Sarker SK, Hossain ABME. Pteridophytes of greater Mymensingh District of Bangladesh used as vegetables and medicines. Bangladesh J Plant Taxon. 1970;16(1):47-56. https://doi.org/10.3329/bjpt.v16i1.2746.

3. Hussaini J, Othman NA, Abdulla MA, Majid NA, Faroq HM, Ismail S. Gastroprotective effects of Dicranopteris linearis leaf extract against ethanolinduced gastric mucosal injury in rats. SRE. 2012;7(18):1761-7. https://doi. org/10.5897/SRE11.775

4. Zakaria, Z. A.; Abdul Ghani, Z. D. F., Raden Mohd Nor, R. N. S.; Gopalan, H. K.; Sulaiman, M. R.; Abdullah, F. CAntinociceptive and anti-inflammatory activities of Dicranopteris linearis leaves chloroform extract in experimental animals. Yakugaku Zasshi 2006, 126 (11), 1197-1203. DOl: https://doi.org/1 0.1248/yakushi.126.1197.

5. Ismail NA, Shamsahal-Din NS, Mamat SS, Zabidi Z, Wan Zainulddin W-N, Kamisan FH, Yahya F, Mohtarrudin N, Mohd-Desa MN, Zakaria ZA. Effect of aqueous extract of Dicranopteris linearis leaves against Paracetamol and carbon tetrachloride-induced liver toxicity in rats. Pak J Pharm Sci. 2014; 27(4):831-5.

6. Lai HY, Lim YY, Tan SP. Antioxidative, Tyrosinase inhibiting and antibacterial activities of leaf extracts from medicinal ferns. Biosci Biotechnol Biochem. 2009;73(6):1362-6. https://doi.org/10.1271/bbb.90018.

7. Zakaria ZA, Mohamed AM, Jamil NSM, Rofiee MS, Somchit MN, Zuraini A, Arifah AK, Sulaiman MR. In vitro cytotoxic and antioxidant properties of the aqueous, chloroform and methanol extracts of Dicranopteris linearis leaves. AJB. 2010;10(2):273-82. https://doi.org/10.5897/AJB10.423.

8. Zakaria ZA, Sodri NH, Hassan H, Anuar K, Abdullah FC. Effects of various receptor antagonists on the peripheral Antinociceptive activity of aqueous extracts of Dicranopteris linearis, Melastoma malabathricum and Bauhinia purpurea leaves in mice. CELLMED. 2012;2(4):38.1-6. https://doi.org/10.5667/ tang.2012.0017.

9. Fisher A, Brandeis R, Bar-Ner RHN, Kliger-Spatz M, Natan N, Sonego H, Marcovitch I, Pittel Z. AF150(S) and AF267B: M1 muscarinic agonists as innovative therapies for Alzheimer's disease. J Mol Neurosci. 2002;19(1-2): 145-53. https://doi.org/10.1007/s12031-002-0025-3.

10. Shekhar A, Potter WZ, Lightfoot J, Lienemann J, Dubé S, Mallinckrodt C, Bymaster FP, McKinzie DL, Felder CC. Selective muscarinic receptor agonist Xanomeline as a novel treatment approach for schizophrenia. Am J Psychiatry. 2008;165(8):1033-9. https://doi.org/10.1176/appi.ajp.2008.06091 591.

11. Moniruzzaman M, Atikur Rahman M, Ferdous A. Evaluation of Sedative and Hypnotic Activity of Ethanolic Extract of Scoparia dulcis Linn https://www. hindawi.com/journals/ecam/2015/873954/ (accessed 7 Jul 2020). https://doi. org/10.1155/2015/873954.

12. Hafiz W, Zilani MNH, Sultana NA, Isalm MM, Anisuzzman M, Hossain MG Neuropharmacological Potential of Ceriscoides turgida (Roxb.) Leaf and Root in Mice. Clinical Phytoscience. 2019;5(1):5. https://doi.org/10.1186/s40816-0190099-X.

13. National Research Council (US) Committee for the Update of the Guide for the Care and Use of Laboratory Animals. Guide for the Care and Use of Laboratory Animals, 8th ed:i The National Academies Collection: Reports funded by National Institutes of Health. Washington (DC): National Academies Press (US); 2011

14. Rd P, Bertin A, Jalfre M. Behavioral despair in mice: a primary screening test for antidepressants. Arch Int Pharmacodyn Ther. 1977:229(2):327-36.

15. Benneh CK, Biney RP, Adongo DW, Mante PK, Ampadu FA, Tandoh A, Jato J, Woode E. Anxiolytic and antidepressant effects of Maerua angolensis DC. Stem Bark Extract in Mice. Depress Res Treat. 2018;2018:1537371. https://doi. org/10.1155/2018/1537371

16. Raja DP, Manickam VS, de Britto AJ, Gopalakrishnan S, Ushioda T, Satoh M, Tanimura A, Fuchino H, Tanaka N. Chemical and Chemotaxonomical studies on Dicranopteris species. Chem Pharm Bull. 1995;43(10):1800-3. https://doi. org/10.1248/cpb.43.1800

17. Zakaria ZA. Free radical scavenging activity of some plants available in Malaysia. Iran J Pharmacol Ther. 2007;6(1):87-0.

18. Pauleti NN, Mello J, Siebert DA, Micke GA, de Albuquerque CAC, Alberton MD, Barauna SC. Characterisation of phenolic compounds of the ethyl acetate fraction from Tabernaemontana catharinensis and its potential antidepressant-like effect. Nat Prod Res. 2018;32(16):1987-90. https://doi. org/10.1080/14786419.2017.1359167.

19. Messaoudi M, Bisson J-F, Nejdi A, Rozan P, Javelot H. Antidepressant-like effects of a cocoa Polyphenolic extract in Wistar-Unilever rats. Nutr Neurosci. 2008;11(6):269-76. https://doi.org/10.1179/147683008X344165.
20. Lin S, Zhou Z, Zhang H, Yin W. Phenolic glycosides from the rhizomes of Cyperus rotundus and their antidepressant activity. J Korean Soc Appl Biol Chem. 2015;58(5):685-91. https://doi.org/10.1007/s13765-015-0092-0.

21. German-Ponciano, L. J.; Rosas-Sánchez, G. U.; Rivadeneyra-Domínguez, E.; Rodríguez-Landa, J. F. Advances in the Preclinical Study of Some Flavonoids as Potential Antidepressant Agents https://www.hindawi.com/journals/ scientifica/2018/2963565/ (accessed 7 Jul 2020). DOl: https://doi.org/10.11 55/2018/2963565

22. Chen $Y$, Han $T$, Qin $L$, Rui $Y$, Zheng $H$. Effect of total triterpenes from Centella asiatica on the depression behavior and concentration of amino acid in forced swimming mice. Zhong Yao Cai. 2003;26(12):870-3.

23. Zhou Y, Shen Y-H, Zhang C, Su J, Liu R-H, Zhang W-D. Triterpene Saponins from Bacopa monnieri and their antidepressant effects in two mice models. J Nat Prod. 2007;70(4):652-5. https://doi.org/10.1021/np060470s.

24. Khisti RT, Chopde CT, Jain SP. Antidepressant-like effect of the Neurosteroid 3alpha-Hydroxy-5alpha-Pregnan-20-one in mice forced swim test. Pharmacol Biochem Behav. 2000;67(1):137-43. https://doi.org/10.1016/ s0091-3057(00)00300-2.

25. Rodrìguez-Landa JF, Contreras CM, Bernal-Morales B, Gutièrrez-Garcìa AG, Saavedra M. Allopregnanolone Reduces Immobility in the Forced Swimming Test and Increases the Firing Rate of Lateral Septal Neurons through Actions on the GABAA Receptor in the Rat. J. Psychopharmacol. (Oxford). 2007;21(1):76-84. https://doi.org/10.1177/0269881106064203.

26. Adongo DW, Kukuia KKE, Mante PK, Ameyaw EO, Woode E. Antidepressantlike effect of the leaves of Pseudospondias microcarpa in mice: evidence for the involvement of the serotoninergic system, NMDA receptor complex and nitric oxide pathway. Biomed Res Int. 2015;2015:397943. https://doi. org/10.1155/2015/397943.

27. Detke MJ, Rickels M, Lucki I. Active behaviors in the rat forced swimming test differentially produced by serotonergic and noradrenergic antidepressants. Psychopharmacology. 1995;121(1):66-72. https://doi.org/1 0.1007/BF02245592.

28. Page ME, Detke MJ, Dalvi A, Kirby LG, Lucki I. Serotonergic mediation of the effects of fluoxetine, but not Desipramine, in the rat forced swimming test. Psychopharmacology. 1999;147(2):162-7. https://doi.org/10.1007/s00213 0051156.

29. Rénéric JP, Lucki I. Antidepressant behavioral effects by dual inhibition of monoamine reuptake in the rat forced swimming test. Psychopharmacology. 1998;136(2):190-7. https://doi.org/10.1007/s00213 0050555.

30. Carr GV, Lucki I. The role of serotonin receptor subtypes in treating depression: a review of animal studies. Psychopharmacology. 2011;213(2-3): 265-87. https://doi.org/10.1007/s00213-010-2097-z.

31. Berrocoso E, Ikeda K, Sora I, Uhl GR, Sánchez-Blázquez P, Mico JA. Active Behaviours produced by antidepressants and opioids in the mouse tail suspension test. Int J Neuropsychopharmacol. 2013;16(1):151-62. https://doi. org/10.1017/S1461145711001842

32. Tsuji $R$, Isobe $N$, Kawasaki H. Mechanism of prolongation of pentobarbitalinduced sleeping time by Empenthrin in mice. Toxicology. 1996;108(3):18590. https://doi.org/10.1016/0300-483x(95)03298-t

\section{Publisher's Note}

Springer Nature remains neutral with regard to jurisdictional claims in published maps and institutional affiliations. 